\title{
Control of the Alphitobius Diaperinus (Panzer) (Coleoptera: Tenebrionidae) with Entomopathogenic Fungi
}

Author(s)
Rezende SRF1
Curvello FA2
Fraga ME ${ }^{3}$
Reis RCS
Castilho AMC
Agostinho TSP5
1 M.Sc. Student in Animal Science of
Universidade Federal Rural do Rio de Janeiro.
2 Professor, Instituto de Zootecnia of
Universidade Federal Rural do Rio de Janeiro.
3 Professor, Instituto de Veterinária of
Universidade Federal Rural do Rio de Janeiro;
4 Biologist MS. Agrobio - Alternative
pesticides.
5 M.Sc student in Zootecnia of Universidade
Federal Rural do Rio de Janeiro.

Mail Address

RFS Rezende

Rua Bela Vista, 151. Bairro Ecologia

Alojamento Pós-Graduação UFRRJ.

BR 465, km 7

23.890-000. Seropédica, RJ, Brazil.

E-mail: sabrinarbio@yahoo.com.br

\section{Keywords}

Alphitobius diaperinus, Beauveria bassiana, Cladosporium sp., Poultry litter, Trichoderma sp.

\section{ABSTRACT}

The beetle Alphitobius diaperinus (Panzer), considered a worldwide pest in the poultry industry, is difficult to control and it is a vector for pathogens. The objective of this study was to evaluate the biological control of the lesser mealworm, by strains of fungi Beauveria bassiana, Cladosporium sp. and Trichoderma sp. Larvae and adults of the $A$. diaperinus were inoculated with suspensions of conidia in the concentration of $10^{7}$ conídia. $\mathrm{mL}^{-1}$. The $B$. bassiana isolate caused higher insect mortality as compared to Cladosporium sp. and Trichoderma sp. isolates, with the larvae being more susceptible than adults. The entomopathogenicity of $B$. bassiana was further evaluated with 200 larvae and 200 adults of $A$. diaperinus inoculated with suspensions $10^{6}$, $10^{7}$, and $10^{8}$ conidia. $\mathrm{mL}^{-1}$, and observed for ten days. Larvae mortality started at the fourth day at the lowest concentration, and the adult mortality was only observed on the sixth day at the concentration of $10^{8}$ conidia. $\mathrm{mL}^{-1}$.

\section{INTRODUCTION}

The beetle Alphitobius diaperinus (Panzer), known as lesser mealworm, belong to the Phylum Arthropoda, Class Insecta, Order Coleoptera, and Family Tenebrionide (Paiva, 2000). Today, it is a major problem in world poultry production, despite being primarily known as a secondary pest of flours, feeds, and stored grain by products. This insect has fully adapted to poultry houses, and it is commonly found in high density in poultry litter, where it feeds from feed, feces, and dead birds.

The lesser mealworm, also known as darkling beetle, is responsible for huge economic losses, as birds scratch the litter and feed on it, with consequent reduction of balanced feed intake, worse feed conversion ratio, and impairment of the birds' early development (Matias, 1992). The consumption of the adult insects may injury the bird digestive tract due to their hard elytrons (Matias, 1992). In addition of the aforementioned losses, the beetles of the Family Tenebrionidae, when disturbed, release a secretion as a defense mechanism against predators. In the case of $A$. diaperinus, quinones were isolated from this secretion. Quinones are toxic and carcinogenic substances that may cause liver lesions, leading to carcass condemnation in the processing plant (Tseng et al., 1971). Moreover, Elowni \& Elbiharis (1979) mentioned that the lesser mealworm larvae injure the birds' skin, damaging bird health and carcass quality.

Lesser mealworms host and are potential transmitters of bacteria, viruses, fungi, protozoa, and plathyhelminths (Despins et al., 1994; Despins e Axtell, 1995; Mcalister et al., 1995). According to De Las Casas et al. (1972), this insect is a vector of avian leukosis, and may host bacteria, such as Streptococcus sp., Bacillus subtilis, 
Corynebacterium sp., Staphylococcus aureus, Escherichia coli, Serratia marcescens, Salmonella typhimurium, in addition to fungi, as Fusarium sp., Aspergillus flavus, and Candida sp. Among the viruses isolated from Alphitobius diaperinus, infectious bursal disease, leukosis, Marek's disease, and Newcastle disease viruses, as well as rotavirus are highlighted (Eidson et al., 1966; De Las Casas et al., 1973). Eimeria sp. oocysts can survive in the litter and be ingested by Alphitobius diaperinus, consequently contaminating broilers (Reyna et al., 1983; Apuya et al., 1994). These pathogens are transmitted when birds ingest infected A. diaperinus larvae and adults.

Alphitobius diaperinus may damage thermal insulation systems in environmentally-controlled poultry houses by perforating the insulating material, impairing thermal comfort, which may be detrimental for birds during initial development, causing reduced weight gain or egg production (Turner, 1986).

Frequent cleaning of the poultry houses, removing the litter after birds are transferred, can be used to reduce lesser mealworm number, despite being expensive and labor-intensive (Steelman, 1996). Most strategies to control this pest are based on the application of chemical insecticides with short residual period. However, their use and efficacy is limited by the continuous presence of birds in the poultry houses, and, despite being efficient, these insecticides may cause bird intoxication. Moreover, as the lesser mealworms usually bury themselves in the litter, the efficiency of these insecticides is also low as they are applied only on the surface of the litter (Alves, 1998).

The need to reduce the environmental impacts caused by the excessive use of pesticides, and to prevent labor hazards, has motivated studies on pest control alternatives, such as the biological control using entomopathogens, which seems to be feasible, particularly when considering bird safety. Entomopathogenic microorganisms have shown to be innocuous to homeothermal animals, not posing risks to the stockperson and the environment. In addition, these microorganisms remain longer in the environment as compared to chemical products (Crawford et al., 1998).

Entomopathogenic fungi present a high potential for pest control due to their capacity to suppress arthropod populations. Except for Beauveria bassiana, there are no evidences in literature on the efficiency of the application of suspensions of Cladosporium sp. and Trichoderma sp. conidia in the control of Alphitobius diaperinus. However, the proven action of these fungi in the control of plant pests suggests that they can potentially be used in the control of the lesser mealworm in poultry production.

The present study aimed at evaluating the pathogenic action of the entomopathogenic fungi Beauveria bassiana, Cladosporium sp., and Trichoderma sp. on lesser mealworms (Alphitobius diaperinus Panzer) and at quantifying the entomopathogenicity of Beauveria bassiana on Alphitobius diaperinus.

\section{MATERIAL AND METHODS}

The in vitro tests were carried out at the Mycology Lab of the Animal Health Project (PSA), under an agreement between UFRRJ and EMBRAPA, located in Seropédica, RJ, Brazil.

The insects were collected from the poultry litter of commercial broiler houses of an integrated company of the state of Rio de Janeiro and transported to the lab in plastic buckets covered with a screen.

In the lab, samples were mechanically cleaned to reduce the content of contaminating material, such as feathers, feces, and feed, as well as other insects. In addition, adult beetles were separated from larvae, out of which those that were one-cm long were selected.

\section{Origin of the isolates}

The following fungi species were used: isolate 12 of Beauveria bassiana (obtained from $A$. diaperinus), isolate 08 of Trichoderma sp. (obtained from soil samples), and isolate 13 of Cladosporium sp. (obtained from an aphid). The fungi were obtained from the collection of PESAGRO - Rio de Janeiro - EES (Experimental Station of Seropédica), and stored in test tubes containing PDA (potato dextrose agar) medium.

\section{Pathogenicity test}

B. bassiana, Trichoderma sp., and Cladosporium sp. cultures were multiplied in PDA culture medium (Alves et al., 1998), incubated in a BOD chamber $\left(26 \pm 1^{\circ} \mathrm{C}\right)$, for seven to ten days. After this period, conidia were collected scraping the medium with the aid of a loop, and transferred to 250-mL Erlenmeyer flasks containing saline solution at $0.85 \% \mathrm{NaCl}+0.1 \%$ Tween 80 . After homogenization, a suspension sample was placed in a Neubauer chamber, and conidia were counted. Conidium suspensions with $10^{7}$ conidia. $\mathrm{mL}^{-1}$ were prepared for each fungus species. Treatments consisted of the fungi suspension and a control treatment (Moraes \& Alves, 1986). 
In the bioassays, 320 insects (160 larvae and 160 adults) were used. Four treatments with four replicates of 10 insects were applied. Insects were transferred to previously sterilized $250-\mathrm{mL}$ beakers, where insects were immersed in $1 \mathrm{~mL}$ suspension containing $10^{7}$ conidia. $\mathrm{mL}^{-1}$, and manually shaken for $10 \mathrm{~s}$, according to the immersion technique described by Loureiro \& Monteiro (2005). In the control treatment, insects were immersed in $1 \mathrm{~mL}$ saline solution $+0.1 \%$ Tween 80 .

Larvae and adults were then transferred to and maintained in Petri dishes lined with paper filter wetted with sterilized distilled water and sterilized broiler feed. The Petri dishes were kept in a BOD incubator (26 \pm $1^{\circ} \mathrm{C}$ ). Mortality was assessed daily for 10 days. Dead individuals were immersed in alcohol solution at $70 \%$, rinsed with distilled water, individually transferred to Petri dishes lined with paper filter wetted with sterilized water, and kept in a BOD incubator BOD $\left(26 \pm 1^{\circ} \mathrm{C}\right)$ for 10 days to allow fungi development and expression, aiming at confirming the presence of the disease causing agent. Treatments were analyzed by the ChiSquare $(\chi 2)$ test.

\section{Virulence test}

The fungus Beauveria bassiana was tested, as it presented entomopathogenicity both for Alphitobius diaperinusl larvae and adults.

Fungal specimens were obtained from the insects that died in the pathogenicity test and that presented fungus expression. The fungus was replicated in tests tubes with PDA culture medium (Alves et al., 1998), incubated in a BOD chamber $\left(26 \pm 1^{\circ} \mathrm{C}\right)$, for seven to ten days. After this period, conidia were collected scraping the medium, and transferred to $250-\mathrm{mL}$
Erlenmeyer flasks containing saline solution at $0.85 \%$ $\mathrm{NaCl}+0.1 \%$ Tween 80. After homogenization, a suspension sample was placed in a Neubauer chamber, and conidia were counted under the microscope. Conidium suspensions with concentrations of $10^{6}, 10^{7}$, $10^{8}$ conidia. $\mathrm{mL}^{-1}$ were prepared (Moraes \& Alves, 1986).

For each treatment, including the control treatment, five replicates of 10 insects were used, totaling 400 individuals, being 200 larvae and 200 adults. Insects were transferred to previously sterilized $250 \mathrm{~mL}$ beakers, where they were immersed in $1 \mathrm{~mL}$ of conidia suspension at concentrations of $10^{6}, 10^{7}$, and $10^{8}$ conidia. $\mathrm{mL}^{-1}$, using thereafter the same methodology applied in the pathogenicity test. Data were submitted to non-parametrical analysis of Kruskal-Wallis, using SAEG software package (Statistical and Genetic Analysis System - UFV, 2007). The LC50 (lethal concentration to kill $50 \%$ of the individuals) was calculated using the statistical method of Probit.

\section{RESULTS AND DISCUSSION}

\section{Pathogenicity test}

Higher insect mortality $(p<0.05)$ was observed with the $B$. bassiana isolate as compared to Thichoderma sp. and Cladosporuim sp. isolates (Tables 1 and 2). This is probably due to pathogen species-specificity, as no hosts may be resistant even to high doses (Alves, 1998).

The confirmed mortality due to the action of $B$. bassiana was $95 \%$ and $62.5 \%$ for larvae and adults, respectively, at a concentration of $10^{7}$ conidia. $\mathrm{mL}^{-1}$. The insect mortality obtained in the present study was higher than that observed by other authors, such as

\begin{tabular}{|c|c|c|c|c|c|c|}
\hline \multirow[t]{2}{*}{ Isolates } & \multicolumn{2}{|c|}{ Live insects } & \multicolumn{2}{|c|}{ Dead insects } & \multicolumn{2}{|c|}{ Total } \\
\hline & $\mathbf{N}$ & $\%$ & $\mathbf{N}$ & $\%$ & $\bar{N}$ & $\%$ \\
\hline Control & 40 & 100 & 0 & 0 & 40 & 100 \\
\hline Beauveria bassiana & 2 & 5 & 38 & 95 & 40 & 100 \\
\hline Trichoderma sp. & 39 & 92.5 & 1 & 7.5 & 40 & 100 \\
\hline Cladosporium sp. & 37 & 97.5 & 3 & 2.5 & 40 & 100 \\
\hline
\end{tabular}

Chi-Square test $(3)=130.815$

Table 2 - In vitro mortality of Alphitobius diaperinus adults treated with Beauveria bassiana, Trichoderma sp, Cladosporium sp.

\begin{tabular}{|c|c|c|c|c|c|c|}
\hline \multirow[t]{2}{*}{ Isolates } & \multicolumn{2}{|c|}{ Live insects } & \multicolumn{2}{|c|}{ Dead insects } & \multicolumn{2}{|c|}{ Total } \\
\hline & $\mathbf{N}$ & $\%$ & $\mathbf{N}$ & $\%$ & $\mathbf{N}$ & $\%$ \\
\hline Control & 40 & 100 & 0 & 0 & 40 & 100 \\
\hline Beauveria bassiana & 15 & 37.5 & 25 & 62.5 & 40 & 100 \\
\hline Trichoderma sp. & 40 & 100 & 0 & 0 & 40 & 100 \\
\hline Cladosporium sp. & 40 & 100 & 0 & 0 & 40 & 100 \\
\hline
\end{tabular}

Chi-Square test $(3)=88.889$. 
Batista et al. (2003), who found maximum A. diaperinus larvicidal action of $17 \%$ and adulticidal action of $29 \%$ using $B$. bassiana at $10^{9}$ conidia. $\mathrm{mL}^{-1}$. Geden \& Steinkraus (2003) found a $60-90 \%$ mortality range of $A$. diaperinus larvae when testing $B$. bassiana in the lab, which was probably due to the fact that they used an isolate (986) obtained from ticks. B. bassiana isolates can be species-specific (Geden et al., 1998), which was demonstrated with $B$. bassiana isolates obtained from naturally-infected lesser mealworm larvae (WV) or from house flies (NC). The insect was more sensitive to the WV isolate at $2.5 \times 10^{11}$ conidia $\mathrm{mL}^{-2}$, which was $100 \%$ effective against larvae. The reported isolate specificity was confirmed by Alves et al. (2005), and may be related to the genetic variability of the isolates (Castrillo et al., 1999).

In the present study, Cladosporium sp. did not cause significant mortality, killing only $2.5 \%$ of the larvae and none of the adults, despite being a naturally occurring entomopathogenic fungus frequently used for the biological control of several species of phytic insects and widely distributed in the air and organic matter (Oliveira et al., 2004). Garcia (2004), testing Cladosporium cladosporioides against Orthezia praelonga, a citrus pest, obtained $1.25 \%$ mortality, and suggested that the used isolate present low virulence, as opposed to Gallo et al. (1978), who observed the association of this fungus with some insect pests. According to Moraes et al. (2001), Cladosporium was observed infecting a cassava fruit fly (Aleurothrixus aepim) in the state of Bahia, with $82 \%$ pathogenicity under artificial infection. Petch (1932) observed that same fungus infecting aphid populations. It naturally attacked mites (Calacarus) in rubber plantations in the regions of Araçatuba and São José do Rio Preto, São Paulo State (Batista Filho et al., 1991), and was associated with the tobacco aphid (Myzus nicotianae) in the states of Paraná and Santa Catarina (Sudo et al., 1995).

As to Trichoderma sp., the mortality was confirmed in only $7.5 \%$ of the larvae and none in adults. On the other hand, Moraes et al. (2001), using Trichoderma against several mosquito strains (Culex quinquefasciatus, Aedes fluviatilis, Aedes aegypti, and Anopheles aquasalis) obtained confirmed mortality of approximately 70\%. Tanzini (2002) found 78\% mortality of fourth-instar nymphs of Leptopharsa haveae, the rubber-tree lace bug, four days after the exposure to a Trichoderma solution, suggesting that this fungus is a promising biocontrol agent.

In the present study, it was observed that the larval stage was more susceptible than the adult stage. This may be related to exoskeletal differences between these development stages. The tegument of adults is more sclerotized than that of larvae, making it more difficult for the pathogen to penetrate. Fungi preferably infect insects through the tegument surface (Boucias \& Pendland, 1998). However, other factors must be considered, such as the genetic variability among different fungi genus and species, natural resistance of some insects (mainly adults), instability of conidia livability, as well as reduced virulence.

\section{Virulence test}

When the cumulative mortality distribution of $A$. diaperinus larvae by the $B$. bassiana isolate was analyzed, it was observed that, in general, larvae presented significant mortality already on the third day of fungus exposure, reaching $62 \%$ and $72 \%$ for the concentrations of $10^{7}$ and $10^{8}$ conidia. $\mathrm{mL}^{-1}$, respectively. Even at the lowest concentration $\left(10^{6}\right.$ conidia. $\left.\mathrm{mL}^{-1}\right)$, mortality was observed after the fourth day of exposure (Table 3).

For the concentration of $10^{6}$ conidia. $\mathrm{mL}^{-1}$, mortality peaked on the fifth day, with $100 \%$ dead larvae, whereas the concentrations of $10^{7}$ conidia. $\mathrm{mL}^{-1}$ and $10^{8}$ conidia. $\mathrm{mL}^{-1}$ killed 94 and $98 \%$ of the larvae, respectively, and tended to stabilize after the sixth day. This difference in larva mortality between the lowest and the higher concentrations may be a result of the effective number of conidia in contact with the insect. This result shows that, depending on the isolate, a relatively low concentration of fungus is sufficient to achieve the goal of larvae control, precluding the need of producing a large "fungus mass".

As to the distribution of the mortality of $A$. diaperinus adults by the $B$. bassiana isolate, it was found that the concentration of $10^{6}$ conidia. $\mathrm{mL}^{-1}$ was not sufficient to cause significant mortality any time

\begin{tabular}{|c|c|c|c|c|c|c|c|c|c|c|}
\hline Treatment & Day 1 & Day 2 & Day 3 & Day 4 & Day 5 & Day 6 & Day 7 & Day 8 & Day 9 & Day 10 \\
\hline Control $0.0 \mathrm{a}$ & $0.0 \mathrm{a}$ & $0.0 \mathrm{a}$ & $0.0 \mathrm{a}$ & $0.0 \mathrm{a}$ & $0.0 \mathrm{a}$ & $0.0 \mathrm{a}$ & $0.0 \mathrm{a}$ & $0.0 \mathrm{a}$ & $0.0 \mathrm{a}$ & \\
\hline $10^{6}$ con. $/ \mathrm{mL}^{-1}$ & $0.0 \mathrm{a}$ & $2.00 \mathrm{a}$ & $16.00 \mathrm{a}$ & $96.00 \mathrm{~b}$ & $100.00 \mathrm{~b}$ & - & - & - & - & - \\
\hline $10^{7}$ con. $/ \mathrm{mL}^{-1}$ & $0.0 \mathrm{a}$ & $8.00 \mathrm{a}$ & $62.00 \mathrm{~b}$ & $92.00 \mathrm{~b}$ & $94.00 \mathrm{~b}$ & $94.00 \mathrm{~b}$ & $94.00 \mathrm{~b}$ & $94.00 \mathrm{~b}$ & $94.00 \mathrm{~b}$ & $94.00 \mathrm{~b}$ \\
\hline $10^{8} \mathrm{con} . / \mathrm{mL}^{-1}$ & $0.0 \mathrm{a}$ & $0.0 \mathrm{a}$ & $72.00 \mathrm{~b}$ & $96.00 \mathrm{~b}$ & $96.00 \mathrm{~b}$ & $98.00 \mathrm{~b}$ & $98.00 \mathrm{~b}$ & $98.00 \mathrm{~b}$ & $98.00 \mathrm{~b}$ & $98.00 \mathrm{~b}$ \\
\hline
\end{tabular}

1 - Means followed by the same letter in the same column are not different $(P>5 \%)$ by the test of Kruskal-Wallis. 


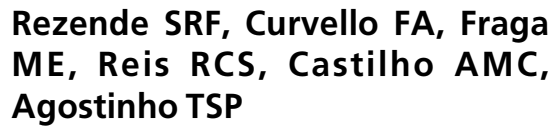

\begin{tabular}{|c|c|c|c|c|c|c|c|c|c|c|}
\hline Treatment & Day 1 & Day 2 & Day 3 & Day 4 & Day 5 & Day 6 & Day 7 & Day 8 & Day 9 & Day 10 \\
\hline Control & $0.0 \mathrm{a}$ & $0.0 \mathrm{a}$ & $0.0 \mathrm{a}$ & $0.0 \mathrm{a}$ & $0.0 \mathrm{a}$ & $0.0 \mathrm{a}$ & $0.0 \mathrm{a}$ & $0.0 \mathrm{a}$ & $0.0 \mathrm{a}$ & $0.0 \mathrm{a}$ \\
\hline $10^{6} \mathrm{con} . / \mathrm{mL}^{-1}$ & $0.0 \mathrm{a}$ & $0.0 \mathrm{a}$ & $0.0 \mathrm{a}$ & $0.0 \mathrm{a}$ & $0.0 \mathrm{a}$ & $0.0 \mathrm{a}$ & $2.00 \mathrm{a}$ & $6.00 \mathrm{a}$ & $8.00 \mathrm{a}$ & $8.00 \mathrm{a}$ \\
\hline $10^{7} \mathrm{con} . / \mathrm{mL}^{-1}$ & $0.0 \mathrm{a}$ & $2.00 \mathrm{a}$ & $2.00 \mathrm{a}$ & $2.00 \mathrm{a}$ & $2.00 \mathrm{a}$ & $12.00 a b$ & $36.00 \mathrm{~b}$ & $48.00 \mathrm{~b}$ & $52.00 \mathrm{~b}$ & $54.00 \mathrm{~b}$ \\
\hline $10^{8} \mathrm{con} . / \mathrm{mL}^{-1}$ & $0.0 \mathrm{a}$ & $2.00 \mathrm{a}$ & $2.00 \mathrm{a}$ & $2.00 \mathrm{a}$ & $28.00 \mathrm{ab}$ & $52.00 \mathrm{~b}$ & $76.00 \mathrm{~b}$ & $82.00 \mathrm{~b}$ & $84.00 \mathrm{~b}$ & $84.00 \mathrm{~b}$ \\
\hline
\end{tabular}

1 - Means followed by the same letter in the same column are not different $(P>5 \%)$ by the test of Kruskal-Wallis.

during the experimental period (Table 4). Adults were significantly sensitive to $B$. bassiana after the fifth day at a concentration of $10^{8}$ conidia. $\mathrm{mL}^{-1}$. On the seventh day, $36 \%$ mortality was observed with $10^{7}$ conidia. $\mathrm{mL}^{-1}$, whereas at the concentration of $10^{8}$ conidia. $\mathrm{mL}^{-1}$, mortality was $76 \%$, which was statistically different. At $10^{8}$ conidia. $\mathrm{mL}^{-1}$ mortality peaked on the ninth day, whereas for the concentration of $10^{7}$ conidia. $\mathrm{mL}^{-1}$, the peak was observed on the tenth day, with $84 \%$ and $54 \%$ confirmed mortality, respectively.

In the present study, the larval stage was more sensitive as compared to the adult stage. This is explained by the fact that the mechanism of infection requires a longer period in adults as compared to larvae due to their cuticle thickness. According to Alves, (1998), the time required for infecting insects may vary between 72 and 120 hours. Fungi preferably infect insects on the surface of the tegument, which is more sclerotized in adults than in larvae, rendering the infection of the former more difficult (Boucias \& Pendland, 1998).

In Brazil, studies with $A$. diaperinus larvae and adults submitted to $B$. bassiana and Beauveria spp. infection demonstrated that there is a wide variation in entomopathogenicity, with mortality values between 11 and 100\% for larvae and 0 and 95\% for adults (Alexandre et al., 2006). Rohde et al. (2006), studying the concentrations of $10^{7}, 10^{8}$, and $10^{9}$ conidia. $\mathrm{mL}^{-1}$ of B. bassiana 10 days after inoculation, observed higher mortality in larvae $(100 \%$ mortality in the highest concentration) as compared to adults. In the present study, B. bassiana was more virulent, as the lowest concentration caused $100 \%$ larvae mortality. Steenberg \& Jespersen (1996) also showed that $A$. diaperinus larvae are distinctively more susceptible than adults when in contact with several $B$. bassiana strains. Adults were approximately 1000 times less susceptible to the fungus $B$. bassiana than young larvae (Geden, 1998).

As opposed to the findings of the present study, Silva (2006) did not observe any effects of $3.4 \times 10^{6}$ and $10^{8}$ conidia. $\mathrm{mL}^{-1}$ Beauveria sp. concentrations on A. diaperinus adults, whereas Batista et al. (2003), evaluating the action of $B$. bassiana at $10^{9}$ conidia. $\mathrm{mL}^{-1}$ on $A$. diaperinus adults and larvae, verified $17 \%$ larvicidal and $29 \%$ adulticidal action. The low efficacy of that fungus determined in the lab tests carried out with lesser mealworms by Silva (2006) may be related to the period of contact of the fungus with that coleopteron.

The present study allowed the observation of the main symptoms of the infection of $A$. diaperinus adults caused by the fungus $B$. bassiana. Among others, infected insects moved less than healthy insects. On the day before they died, the insects laid on their backs; the legs were spread away from the body and moved very slowly when touched. At the time of death, the insects were stiff and dry, the legs were spread away from the body, and the tegument color was lighter as compared to healthy insects. The pathogen started to appear on the body of the insect through its natural openings two days after storage in wet chamber, and after four and five days, the insect body was almost completely covered by the fungus (Figure 1).

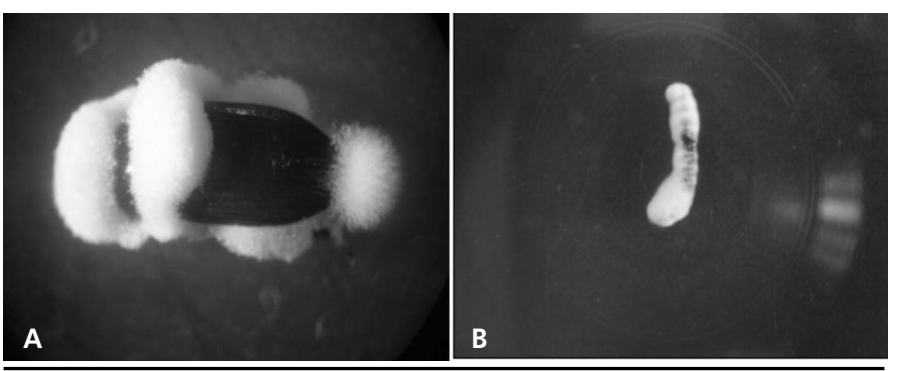

Figure 1 - A) Alphitobius diaperinus adult infected with Beauveria bassiana; B) Alphitobius diaperinus larva infected with Beauveria bassiana.

The lowest lethal concentration value $\left(\mathrm{LC}_{50}\right)$ of $B$. bassiana for Alphitobius diaperinus larvae was $1.02 \times$ $10^{9}\left(2.12 \times 10^{4}-1.23 \times 10^{13}\right)$ obtained on day three, and $\mathrm{LC}_{50}$ for adults was $1.13 \times 10^{9}\left(1.18 \times 10^{13}-5.21 \times\right.$ $\left.10^{24}\right)$, obtained on day 10 . These values demonstrate that the isolate 12 of $B$. bassiana is more virulent to larvae than to adults.

\section{CONCLUSIONS}

Although relatively low concentrations of the 


\section{Rezende SRF, Curvello FA, Fraga ME, Reis RCS, Castilho AMC, Agostinho TSP}

Beauveria bassiana killed Alphitobius diaperinus larvae, the need of a higher concentration to kill adults, as observed in the present study, should be considered in studies aiming at future application of this fungus to control the lesser mealworm, as different stages of Alphitobius diaperinus are present in a same poultry farm.

The results suggest that $B$. bassiana is a promising fungus to be used in the control of that pest, but further studies are warranted to define more precisely the application of this agent in the control of the lesser mealworm, taking always into consideration the costbenefit relationship and the environmental conditions of poultry farms.

\section{REFERENCES}

Alexandre TM, Alves LFA, Neves PMOJ, Alves SB. Efeito da temperatura e substrato sobre Beauveria bassiana e Metarhizium anisopliae e sua relação no controle do cascudinho (Alphitobius diaperinus) (Panzer) (Coleoptera: Tenebrionidae). Neotropical Entomology 2006; 35:75-82.

Alves LFA, Gassen MH, Pinto FGS, Neves PMOJ, Alves SB. Ocorrência natural de Beauveria bassiana (Bals.) Vuilleman (Moniliales: Moniliaceae) sobre o cascudinho, Alphitobius diaperinus (Panzer) (Coleoptera: Tenebrionidae), em aviário comercial de Cascavel, PR. Neotropical Entomology 2005; 34:507-510.

Alves SB. Fungos entomopatogênicos. In: Alves, S.B. Controle microbiano de insetos. Piracicaba: Fealq; 1998. p.289-381.

Apuya LC, Stringram SM, Aredens JJ, Broocks WM. Prevalence of protozoan infections in darkling beetles from poultry houses in North Carolina. Journal of Invertebrate Pathology 1994; 63:255259.

Batista Filho A, Leite LG, Furtado EL, Silveira AP, Ortolani AA, Alves LFA, Leitão AEF. Ocorrência natural de Cladosporium sp. atacando Calacarus sp., em cultura de seringueira. Resumos da 4th Reunião Anual do Instituto Biológico; 1991; Campinas, São Paulo. Brasil. p.21-22.

Batista JSS. Influência do meio de cultivo na virulência de isolados do fungo entomopatogênico Beauveria bassiana (Bals.) Vuil. Anais da $18^{\circ}$ Semana de Biologia, Cascavel, Paraná. Brasil: Unioeste; 2003.

Boucias DG, Pendland JC, Principles of insect pathology. Boston: Kluwer Academic Publishers; 1998. p.259-283.

Castrillo LA, Wiegmann BM, Brooks WM. Genetic variation in Beauveria bassiana populations associated with the darkling beetle, Alphitobius diaperinus. Journal of Invertebrate Pathology 1999; 73:269-275

Crawford PJ, Brooks WM, Arends JJ. Efficacy of field-isolated strains of Beauveria bassiana (Moniliales: Moniliaceae) as microbial control agents of the lesser mealworm (Coleoptera: Tenebrionidae). Journal of Economic Entomology 1998; 91:1295-1301.
De Las Casas E, Harein PK, Pomeroy BS. Bacteria and fungi within the lesser mealworm collected from poultry brooder houses. Environmental Entomology 1972; 1(1):27-30.

De Las Casas E, Harein PKD, Eshmuck DR, Pomeroy BS. The relationship between the lesser mealworm and avian viruses. I. Reovirus 24. Environmental Entomology 1973; 2:1043-1047.

Despins JL, Axtell RC. Feeding behavior and growth of broiler chicks fed larvae of the darkling beetle, Alphitobius diaperinus. Poultry Science 1995; 74:331-336.

Despins JL, Axtell RC, Rives DV, Guy JS, Ficken MD. Transmission of enteric pathogens of turkeys by darkling beetle larva (Alphitobius diaperinus). Journal of Applied Poultry Research 1994; 3:61-65.

Eidson CS, Schmittle SC, Goode RB, Lal JB. Induction of leukosis tumors with the beetle Alphitobius diaperinus. American Journal Veterinary Research 1966; 27(119):1053-7.

Elowni EE, Elbiharis S. Natural and experimental infection of the beetle Alphitobius diaperinus with choanotaenia infundibulum and other chicken tapeworms. Veterinary Science Communications 1979: 3:171-173.

Gallo D, Nakano O, Silveira Neto S, Carvalho RPL, Batista GC, Berti Filho E, Parra JRP, Zucchi RA. Manual de entomologia agrícola. São Paulo: Agronômica Ceres; 1978. p.649.

Garcia MO. Utilização de fungos entomopatoginicos para controle de orthazia praelonga (sternorryncha: Ortheziidae) [dissertação]. Piracicaba (SP): Escola Superior de Agricultura Luiz de Queiroz, Universidade de São Paulo; 2004.

Geden CJ, Arends JJ, Ruttz DA, Steinkraus DC. Laboratory evaluation of Beauveria bassiana (Moniliales: Moniliaceae) against the lesser mealworm, Alphitobius diaperinus (Coleoptera: Tenebrionidae), in poultry litter, soil and a pupal trap. Biological Control 1998; 13:71-77.

Geden CJ, Steinkraus DC. Evaluation of three formulations of Beauveria bassiana for control of lesser mealworm and hide beetle in Georgia poultry houses. Journal of Economic Entomology 2003; 96:1602-1607.

Loureiro ES, Monteiro AC. Patogenicidade de isolados de três fungos entomopatogênicos a soldados de Atta sexdens sexdens (Linnaeus, 1758) (Hymenoptera: formicidae). Revista Árvore 2005; 29:553-561.

Matias RS. Controle Alphitobius diaperinus em piso de cama de aviários. Pesquisa Agropecuária Brasileira 1992; 27:205-207.

Mcallister JC, Steelman CD, Newberry LA, Skeeles JK. Isolation of Bursal Disease virus from the lesser mealworm, Alphitobius diaperinus (Panzer). Poultry Science 1995; 74:45-9.

Moraes AML, Borba CM, Costa GL, Rodrigues K, Sarquis MIM. Fungos: ferramentas na saúde pública. Biotecnologia Ciência \& Desenvolvimento 2001; 3(18):10-11.

Moraes AS, Alves SB. Quantificação de inoculo de patógenos de 
insetos. In: Alves, S.B. Controle microbiano de insetos. Piracicaba: Fealq; 1986. p.278-288

Oliveira JS, Souza SE, Oliveira LL, Carvalho JS, Moreira DMO. Distribuição do fungo Cladosporium cladosporioides em regiões de produtores de café da Bahia. Bahia Agrícola 2004; 6(3):72-75.

Paiva DP. Controle de moscas e cascudinhos. Desafios na produção agrícola. Anais do Simpósio Sobre Resíduos da Produção Avícola; 2000; Concórdia, Santa Catarina. Brasil: Embrapa de Suínos e Aves; 2000.

Petch T. Notes on entomogenous fungi. Transactions of the British Mycological Society 1935; 19:55-75.

Reyna PS, Mcdadougald LR, Mathis GF. Surviral of cocida in poutry litter and reservoirs of infection. Avian Disease 1983; 27:464-473.

Rohde C, Alves LFA, Neves PMOJ, Alves SB, Silva ERL, Almeida JEM. Seleção de isolados de Beauveria bassiana (Bals.) Vuill. e Metarhizium anisopliae (Metsch.) Sorok. contra o cascudinho Alphitobius diaperinus (Panzer) (Coleoptera: Tenebrionidae). Neotropical Entomology 2006; 35:231-240.

Silva AS, Quiltal APN, Monteiro SG, Doyle RL, Santurio JM, Bittencourt VREP. Ação do fungo Beauveria bassiana, isolado 986, sobre o ciclo biológico do cascudinho Alphitobius diaperinus em laboratório. Ciência Rural 2006; 36(6):1944-1947.

Sistema de análises estatísticas e genéticas: manual do usuário versão 9.1. Viçosa (MG): Universidade Federal de Viçosa; 2007. 150 p.

Steelman D. Darkling beetles are costly pests. Poultry Digesty 1996; $55: 22-23$

Steenberg T, Jespersen JB. Entomopathogenic fungi for control of litter beetles. Copenhagen: Danish Pest Infestation Laboratory; 1996. p.72-73.

Sudo S, Melo ABP, Galina E. Biological control of Tabaco Aphids. Oxford: CORESTA; 1995. p.6.

Tanzini MR. Controle do percevejo-de-renda-da-seringueira Leptopharsa heveae com fungos entomopatogênicos [tese]. Piracicaba (SP): Escola Superior de Agricultura, Luiz de Queiroz, Universidade de São Paulo; 2002.

Tseng YL, Davidson JA, Menzer RE. Morphology and chemistry of the odorifroos gland of the lesser mealworm, $A$. diaperinus (Coleoptera: Tenebrionidae). Annals Entomology of Society American 1971; 64:425-430.

Turner EC. Structural and litter pests. Poultry Science 1986; 65: 425-430. 